\title{
The effect of the Ketostop-EL feed supplement on the clinical and metabolic status of lactating cows
}

\author{
N.B. Nikulina*, and E.V. Baidak \\ Perm SATU, Perm, Russia
}

\begin{abstract}
A study was conducted on dairy cows aged 3-6 lactation, which were additionally fed with the Ketostop-El supplement at the rate of $300 \mathrm{~g}$ per head for 4 weeks after calving. The use of the feed supplement for 14 days led to a decrease in the number of monocytes, total protein, glucose, creatinine, total calcium and the activity of ALT and AST compared to their level before the use of Ketostop-El. Changes in the physical and chemical properties of urine and increase in the average daily milk yield were noted. The use of the supplement for 28 days contributed to a decrease in hematocrit, the sorption capacity of red blood cells, total protein, glucose, bilirubin, creatinine, total calcium, reserve alkalinity, ALT and AST activity and an increase in the number of basophils, eosinophils, and the concentration of inorganic phosphorus compared to the initial data. At the same time, a decrease in the level of protein and ketones in the urine was observed. An increase in the average daily milk yield and the mass fraction of fat in milk was also recorded. The feed supplement "Ketostop-El" has a positive effect on the body of dairy cows, as evidenced by the normalization of the clinical and metabolic status, as well as an increase in the dairy productivity of animals.
\end{abstract}

\section{Introduction}

The current stage of animal husbandry development is characterized by an increase in animal productivity, an increase in the use of feed nutrients, automation of processes, and high profitability. In this regard, the problem of full-fledged feeding of lactating cows becomes important, which should be aimed at meeting the needs of animals, both in the main nutrition factors and in individual nutrients [1-3]. The consequences of inferiority and unbalanced diets are the cause not only of the spread of metabolic diseases, but also of a decrease in the productivity of cows [4-6].

Currently, it is not possible to optimize the feeding of farm animals without the widespread use of biologically active substances. Feed supplements containing growth

\footnotetext{
${ }^{*}$ Corresponding author: uralskay114@yandex.ru
} 
stimulants, hormones and pharmacological preparations, including antibiotics, are widely used in agricultural enterprises [1-3, 5-14].

We have previously shown that the feed supplement "Ketostop-El" contributes to the improvement of the qualitative and quantitative composition of milk in young cows [15].

The purpose of this work was to evaluate the effect of the Ketostop-El feed supplement on the clinical and metabolic status of lactating cows.

\section{Materials and methods}

The studies were conducted on dairy cows of a black-and-white breed with a live weight of 450-500 kg, aged 3-6 lactation, in the first phase of lactation in the SEC "Chapaev Collective Farm" of the Kungur district of the Perm region. For all animals a year-round stable system of maintenance was used. The farm used a basic diet consisting of silage, haylage, mixed feed, sunflower cake and feed salt. Daily cows were fed with the feed supplement " Ketostop-El "(LLC "Elest", Russia) at the rate of $300 \mathrm{~g}$ per head for 4 weeks after calving

The clinical state of the cows was evaluated according to the generally accepted method. In the morning, before feeding, blood was taken from the cows. The Vet Scan HM5 hematology analyzer was used to determine the red blood cell count, hemoglobin, hematocrit, mean corpuscular volume, average hemoglobin content in red blood cell, average hemoglobin concentration in red blood cell, variation coefficient of red blood cell size, width of variation distribution by volume, count of white blood cells, basophils, eosinophils, neutrophils, lymphocytes, monocytes, platelets, plateletcrit, mean platelet volume, variation coefficient of platelet size, width of platelet distribution by volume.

According to the method of A.Ya. Togaibayev (1988), based on the degree of dye absorption depending on the functional state of the cell membrane, the sorption capacity of red blood cells (CSE) was studied.

The concentration of total protein, urea, glucose, creatinine, bilirubin, triglycerides, total calcium, inorganic phosphorus, reserve alkalinity and activity of aspartate aminotransferase (AST) and alanine aminotransferase (ALT) were studied in the blood serum of animals [16].

In the urine with the helpof indicator test strips "Uripolian-11A "(BIOS company) the count of white blood cells, red blood cells, hemoglobin, protein, glucose, ketone and urine $\mathrm{pH}$ were detected. Microscopy of the urinary sediment was carried out.

The level of milk productivity, the mass fractions of fat and protein in milk were determined by the results of control milking. The obtained data were processed statistically.

\section{Results of the study and discussions}

The zoohygienic parameters of the microclimate in the cowshed in the summer period met the regulatory requirements. The analysis of the diet composition showed that it did not correspond to the physiological needs of cows. An excess of crude protein, metabolic energy, calcium and a lack of dry matter, phosphorus, crude fat, sugar, and crude fiber were found.

Body temperature, respiratory rate and pulse rate in all animals were consistent with physiological values. The fatness index of cows averaged 2.4 points. The matting of the coat, the fragility of the hair was noted. Laminitis was found in $30 \%$ of the animals, as a result of which the animals took a forced posture when standing, showed signs of 
hypodynamia. Also, $80 \%$ of cattle recorded a decrease in appetite, weak rumination, putrid odor from the oral cavity. $20 \%$ of the animals had a dysorexia.

The main hematological parameters in cows before the inclusion of the feed supplement in the diet corresponded to the reference values (Table 1). Nevertheless, there was a slight decrease in the amount of hemoglobin and eosinophil count in the blood of animals compared to the average indicators.

The sorption capacity of red blood cells in cows averaged $45.9 \pm 0.6 \%$. In $30 \%$ of cows with clinical signs of laminitis and digestive disorders, the CSE increased by an average of $14.6 \%$ compared to those in animals of the first group and amounted to $48.6 \pm 0.1 \%$, which indicates the occurrence of endogenous intoxication.

Table 1. Indicators of red blood of dairy cows before and after the introduction of the feed supplement, $\mathrm{M} \pm \mathrm{m}$.

\begin{tabular}{|l|c|c|c|c|}
\hline \multicolumn{1}{|c|}{ Indicators } & $\begin{array}{c}\text { Before } \\
\text { introduction } \\
\text { of the } \\
\text { supplement }\end{array}$ & $\begin{array}{c}\text { 14 days after } \\
\text { introduction } \\
\text { of the } \\
\text { supplement }\end{array}$ & $\begin{array}{c}28 \text { days after } \\
\text { introduction } \\
\text { of the } \\
\text { supplement }\end{array}$ & $\begin{array}{c}\text { Reference } \\
\text { values }\end{array}$ \\
\hline Red blood cells, $10^{12} / 1$ & $6.3 \pm 0.3$ & $6.7 \pm 0.1$ & $6.1 \pm 0.1$ & $5.0-7.5$ \\
\hline Hemoglobin, g/1 & $93.8 \pm 0.3$ & $92.8 \pm 0.2$ & $89.6 \pm 0.3$ & $100.0-129.0$ \\
\hline Hematocrit, \% & $35.2 \pm 1.3$ & $34.1 \pm 0.9$ & $33.9 \pm 0.6$ & $35.0-45.0$ \\
\hline $\begin{array}{l}\text { Mean corpuscular volume, } \\
\text { microns }\end{array}$ & $55.8 \pm 2.2$ & $51.4 \pm 1.2$ & $52.6 \pm 1.1$ & $40.0-60.0$ \\
\hline $\begin{array}{l}\text { Average hemoglobin content } \\
\text { in the red blood cell, pg }\end{array}$ & $14.9 \pm 0.3$ & $14.2 \pm 0.4$ & $14.8 \pm 0.2$ & $11.0-17.0$ \\
\hline $\begin{array}{l}\text { Average concentration of } \\
\text { hemoglobin in the red blood } \\
\text { cell, g/dl }\end{array}$ & $26.6 \pm 0.5$ & $27.3 \pm 0.3$ & $28.1 \pm 0.4$ & $30.0-36.0$ \\
\hline $\begin{array}{l}\text { Variation coefficient of red } \\
\text { blood cell size, \% }\end{array}$ & $20.6 \pm 0.3$ & $21.0 \pm 0.4$ & $21.8 \pm 0.2$ & \\
\hline $\begin{array}{l}\text { Width of the distribution of } \\
\text { red blood cells by volume, } \\
\text { microns }\end{array}$ & $44.7 \pm 1.8$ & $42.3 \pm 1.1$ & $44.7 \pm 1.2$ & \\
\hline White blood cells, 10 $/ 1$ & $6.1 \pm 0.9$ & $6.5 \pm 0.6$ & $6.7 \pm 0.8$ & $4.5-12.0$ \\
\hline Basophils, \% & $0.8 \pm 0.5$ & $0.9 \pm 0.2$ & $1.1 \pm 0.4$ & $0-2.0$ \\
\hline Eosinophils, \% & $2.5 \pm 1.5$ & $2.7 \pm 0.7$ & $3.3 \pm 0.8$ & $3.0-8.0$ \\
\hline Neutrophils, \% & $35.1 \pm 4.3$ & $39.9 \pm 1.2$ & $36.4 \pm 1.4$ & $26.0-37.0$ \\
\hline Lymphocytes, \% & $57.6 \pm 5.3$ & $55.1 \pm 1.0$ & $55.9 \pm 1.2$ & $40.0-65.0$ \\
\hline Monocytes, \% & $4.0 \pm 1.4$ & $1.3 \pm 0.8$ & $2.8 \pm 0.8$ & $2.0-7.0$ \\
\hline Platelets, 10\%/1 & $282.4 \pm 9.7$ & $292.8 \pm 1.5$ & $272.8 \pm 1.6$ & $200.0-700.0$ \\
\hline $\begin{array}{l}\text { Mean platelet volume, } \\
\text { microns }\end{array}$ & $7.0 \pm 0.4$ & $6.9 \pm 0.5$ & $6.6 \pm 0.4$ & $6.0-9.0$ \\
\hline Plateletcrit, \% & $31.4 \pm 1.1$ & $31.8 \pm 0.6$ & $30.4 \pm 0.8$ & $0.1-0.4$ \\
\hline $\begin{array}{l}\text { Variation coefficient of } \\
\text { platelet size, \% }\end{array}$ & $8.7 \pm 0.7$ & $9.2 \pm 0.4$ & $8.1 \pm 0.5$ & \\
\hline $\begin{array}{l}\text { Width of the distribution of } \\
\text { platelets by volume, } \\
\text { microns }\end{array}$ & $0.2 \pm 0.1$ & $0.2 \pm 0.1$ & \\
\hline
\end{tabular}


The study of biochemical parameters revealed an increase in the level of bilirubin in the blood serum of dairy cows by an average of $40 \%$ compared to the reference values and an unreliable increase in the concentration of total protein and reserve alkalinity (Table 2).

Analysis of the physico-chemical properties of urine showed that the average specific density of urine was $1,028 \pm 0.001, \mathrm{pH}-8.4 \pm 0.2$, protein content of $1.16 \pm 0.02 \mathrm{~g} / \mathrm{l}$, ketones - $1.6 \pm 0.4 \mathrm{mmol} / \bar{l}$, which did not correspond to the average physiological indicators. At the same time, the presence of red blood cells and hemoglobin in the urine was noted in $10 \%$ of cows, which indicated a violation of the functioning of the kidneys.

The average daily milk yield was $25.4 \pm 0.2 \mathrm{~kg}$ of milk, the amount of milk fat and protein was $3.82 \pm 0.01 \%$ and $3.12 \pm 0.02 \%$, respectively. The milk consistency was homogeneous. The color, taste and smell corresponded to high-quality milk.

Table 2. Biochemical parameters of the blood serum of cows before and after the application of the feed supplement, $\mathrm{M} \pm \mathrm{m}$.

\begin{tabular}{|l|c|c|c|c|}
\hline \multicolumn{1}{|c|}{ Indicators } & $\begin{array}{c}\text { Before } \\
\text { introduction } \\
\text { of the } \\
\text { supplement }\end{array}$ & $\begin{array}{c}14 \text { days after } \\
\text { introduction } \\
\text { of the } \\
\text { supplement }\end{array}$ & $\begin{array}{c}28 \text { days after } \\
\text { introduction } \\
\text { of the } \\
\text { supplement }\end{array}$ & $\begin{array}{c}\text { Reference } \\
\text { values }\end{array}$ \\
\hline Total protein, g/l & $91.60 \pm 1.20$ & $70.00 \pm 1.60$ & $81.00 \pm 1.10$ & $72.00-86.00$ \\
\hline Glucose, $\mathrm{mmol} / 1$ & $2.86 \pm 0.40$ & $1.92 \pm 0.20$ & $2.38 \pm 0.10$ & $2.22-3.33$ \\
\hline Urea, $\mathrm{mmol} / \mathrm{l}$ & $3.79 \pm 0.32$ & $5.32 \pm 0.22$ & $4.44 \pm 0.20$ & $3.34-6.68$ \\
\hline Alanine transaminase, u/l & $48.80 \pm 1.30$ & $31.00 \pm 1.10$ & $28.60 \pm 0.80$ & $1.30-60.00$ \\
\hline $\begin{array}{l}\text { Aspartate aminotransferase, } \\
\text { u/l }\end{array}$ & $129.00 \pm 4.40$ & $97.80 \pm 2.20$ & $88.40 \pm 2.00$ & $11.00-160.00$ \\
\hline Total bilirubin, umol/1 & $7.17 \pm 0.83$ & $6.55 \pm 0.80$ & $3.26 \pm 0.60$ & $0.20-5.10$ \\
\hline Triglycerides, mmol/1 & $0.21 \pm 0.02$ & $0.20 \pm 0.03$ & $0.20 \pm 0.01$ & $0.20-0.60$ \\
\hline Creatinine, umol/1 & $161.20 \pm 1.10$ & $72.80 \pm .090$ & $69.60 \pm 0.80$ & $88.00-162.00$ \\
\hline Total calcium, mmol/1 & $2.74 \pm 0.05$ & $2.40 \pm 0.06$ & $2.24 \pm 0.04$ & $2.50-3.12$ \\
\hline $\begin{array}{l}\text { Inorganic phosphorus, } \\
\text { mmol/1 }\end{array}$ & $1.46 \pm 0.02$ & $1.84 \pm 0.02$ & $1.86 \pm 0.01$ & $1.45-1.94$ \\
\hline $\begin{array}{l}\text { Ratio of calcium and } \\
\text { phosphorus }\end{array}$ & 1.88 & 1.30 & 1.20 & $1.60-1.72$ \\
\hline Reserve alkalinity, vol $\% \mathrm{CO}_{2}$ & $69.30 \pm 1.10$ & $52.80 \pm 1.00$ & $50.20 \pm 1.00$ & $46.00-66.00$ \\
\hline
\end{tabular}

14 days after the start of the use of the Ketostop-El feed supplement, animal fatness did not change significantly and averaged 2.6 points. $30 \%$ of the cows had signs of laminitis, but the lameness was less pronounced. Signs of gastrointestinal dysfunction were recorded only in $50 \%$ of cows with the preservation of weak rumination and putrid odor from the oral cavity. No dysorexia was detected.

The inclusion of a feed supplement in animal diet led to a decrease in the number of monocytes in the blood by an average of 3 times (Table1) and an unreliable decrease in CSE compared to their level before the use of Ketostop-El. In animals with impaired gastrointestinal tract function, the CSE was $46.9 \%$.

At the same time, a decrease in total serum protein was recorded by an average of $23 \%$, glucose - by $33 \%$, creatinine - by 2.2 times, total calcium - by $12 \%$, ALT and AST activity - by $36 \%$ and $24 \%$, respectively, compared with those before the use of the feed supplement (Table 2).

Changes in the physico-chemical properties of urine were noted. Thus, a decrease in the concentration of protein and ketones in the urine was recorded by an average of $37 \%$ and 2 times, respectively, compared with their level in cows before using the supplement. 
The average daily milk yield in these animals increased by an average of $3.4 \%$ and the mass fraction of fat in milk increased unreliably compared to those before the use of the supplement.

After 28 days, screening of lactating cows showed the following results. The animal fatness was at the level of 3.2 points, the quality of the wool was visually improved (the hair became strong, shine appeared). Clinical signs of laminitis remained in $10 \%$ of cows. The rumen contraction rate increased, an increase in appetite and activity of cows was noted.

The use of Ketostop-El for 28 days contributed to an unreliable decrease in red blood cell count and hematocrit in animals compared to those before the use of the supplement in the diet (Table 1). The sorption capacity of red blood cells of dairy cows was normalized and averaged $45.7 \%$. When studying the leucogram of dairy animals, an increase in the number of basophils and eosinophils was noted by an average of 37 and $32 \%$, respectively, and a decrease in monocytes by an average of $30 \%$ compared to their initial level.

The content of total protein in the blood serum of cows decreased by an average of 12 $\%$, glucose - by $17 \%$, bilirubin - by $54 \%$, creatinine - by 2.3 times, total calcium - by $7 \%$, reserve alkalinity - by $15 \%$, ALT and AST activity decreased by an average of 41 and $31 \%$, respectively, and the concentration of inorganic phosphorus increased by an average of $27 \%$ compared to those before the use of the supplement (Table 2).

At the same time, the level of protein in the urine decreased by an average of 3 times, ketones - by 5 times compared to those before the inclusion of the supplement in the diet of cows.

Also, an increase in the average daily milk yield and the mass fraction of fat in milk was recorded by an average of 8.2 and $4.2 \%$ compared to their level before the use of KetostopEl, which indicated an increase in the dairy productivity of cows. The physico-chemical properties of the milk obtained from cows after the application of the additive did not differ from the initial level.

As it is known, after calving, cows undergo significant changes in homeostasis, which are caused by physiological increasing the milk yield, changes in the intensity of metabolism, and involutional processes in the uterus $[3,12,14]$. All these processes require large energy and plastic reserves of animals. The diet during this period cannot provide the animal with energy in full, even if it is maximally balanced in terms of nutrients and biologically active substances. As a result, in the first phase of lactation, a negative energy balance is formed, which the cow compensates by mobilizing the body's resources, which leads to a loss of live weight $[3,4,9,10]$.

The changes in the physiological status of animals and low fatness noted by us are probably due to an imbalance of nutrients in the diet and a rearrangement of metabolism in animals. In addition, an excess of protein in the diet, a lack of fiber and dry matter contributed to increased formation of ammonia in the rumen, a shift of the rumen $\mathrm{pH}$ to the alkaline side and the development of the initial stage of alkalosis in cows [17-19], as evidenced by an increase in the reserve alkalinity of the blood, urine $\mathrm{pH}$ and a low concentration of inorganic phosphorus in the blood. This was accompanied by intoxication of the body, deterioration of the clinical condition of the animals in the form of digestive disorders and the occurrence of laminitis.

The inclusion of "Ketostop-El" in the diet of animals for 14 days led to an improvement in the clinical condition and increased milk productivity of cows. A decrease in the proportion of monocytes in the blood may be associated with the migration of these cells to the uterus and mammary gland to provide anti-inflammatory effects. In addition, a decrease in the concentration of protein, creatinine, ALT and AST activity in the blood serum of animals indicated normalization of the metabolic status and improved functioning of the 
liver and kidneys. Nevertheless, there was also a significant decrease in the level of glucose in the blood serum of cows, which is probably due to a decrease in appetite and inadequate feed intake after calving, due to hormonal restructuring and the impact of stress factors, as well as an insufficient amount of sugar in the diet.

Further use of Ketostop-El contributed to the restoration of the clinical status of cows. There was also an increase in the sorption capacity of red blood cells, the number of basophils, eosinophils and monocytes to the level of physiological values. There was an increase in the level of glucose and total protein in the blood serum of cows and a simultaneous decrease in the concentration of bilirubin, urea, creatinine, ALT and AST activity, reserve alkalinity compared to those after 14 days of supplement inclusion in the diet. Normalization of biochemical parameters of blood serum was accompanied by a change in the physico-chemical properties of animal urine, which indicates a positive effect of "Ketostop-El" on the body of cows.

The results of our research showed that the additional use of feed additives in the diet of lactating cows led to an increase in the milk productivity of animals and an increase in fat content.

The improvement of the clinical and metabolic status of cows can be explained by the fact that "Ketostop-El" is a complex supplement. The composition of the feed supplement includes propylene glycol, which can be a source of endogenous glucose, which allows to eliminate the causes of energy deficiency in animals. In addition to propylene glycol, it contains propionate and succinic acid, which restore liver function and blood glucose levels. Dietary fiber contributes to an increase in the amount of saliva, which plays the role of a buffer system, and as a result, reduces the $\mathrm{pH}$ of the rumen contents, eliminating the causes of alkalosis development. Organic acids are used by the rumen microflora for growth and development, which leads to an increase in the formation of protein in the rumen. In addition, the supplement contains zeolites, which play an important role in detoxifying the body and reducing the level of ammonia in the body.

\section{Conclusions}

The feed supplement "Ketostop-El" has a positive effect on the body of dairy cows, as evidenced by the normalization of the clinical and metabolic status, as well as an increase in the dairy productivity of animals. The inclusion of the supplement in cattle diet will help to level food stress and reduce the time of adaptation of animals after calving.

\section{References}

1. Yu.A. Baldzhi, Yu.N. Sheiko, V.V. Polyakov, S.P. Seidenova, et al., Bulletin of meat cattle breeding, 2(94), 59-63 (2016).

2. I.Sh. Madyshev, R.N. Fayzrakhmanov, I.N. Kamaldinov, Scientific notes of the Kazan State Academy of Veterinary Medicine n.a. N.E. Bauman 32(4), 105-108 (2017)

3. V.F. Pozdnyakova, O.V. Latysheva, I.A. Timinskaya, A.V. Ivanov, et al., Agrarian Bulletin of the Urals 08(175), 41-46 (2018)

4. E.N. Tyurenkova, O.R. Vasilyeva, Farm animals, 2, 100-110 (2014)

5. L.M. Chagas, J.J. Bass, D. Blache, C.R. Burke and all., J. Dairy Sci. 90, 4022-4032 (2007)

6. D.C. Wathes, A.M. Clempson, G.E. Pollott., Reprod. Fertil. Dev. 25, 48-61 (2012) 
7. N.A. Nikolaeva, N.M. Alekseeva, P.P. Borisova, E.S. Vasilyeva, et al., International Agricultural Journal, 3(369), 55-58 (2019)

8. N. Garcia-Fernandez, F. Díaz, Six dairy cattle feed additive research insights https://www.researchgate.net/publication/330105955.

9. Immig I. Using feed additives to improve milk production and dairy farm efficiency. International Dairy Topics, http://www.positiveaction.info/pdfs/articles/dt13_5p31.pdf.

10. A. Ivanov, A. Betin. The effectiveness of the use of feed additive Agolin Ruminant in the rations of lactating cows. https://www.researchgate.net/publication/345911889.

11. C.K. Reynolds, G.B. Huntington, H.F. Tyrrell, P.J. Reynolds, Journal of Dairy Science 71(9), 2395-2405 (1988)

12. J. Rodenburg, Feed Additives for the Dairy Herd: A Literature Review and Discussion of Practical Applications. https://www.ncbi.nlm.nih.gov/pmc/articles/PMC1680065/p df/canvetj00601-0058.

13. D.J. Schingoethe, Journal of Dairy Science 100 (12), 10143-10150 (2017)

14. D. Voicu, M. Nicolae, I. Ioanca et all., Use of feed additives as source of fat and fatty acids on cow milk production and quality. Archiva Zootechnica. 9 (2006)

15. N.B. Nikulina, E.V. Baidak, The effectiveness of the use of the feed supplement "Ketostop-El" to increase the milk productivity of cows, Agrotechnologies of the XXI century: development strategy, technologies and innovations. Materials of the AllRussian scientific and practical conference dedicated to the 90th anniversary of the University's foundation (Perm, October 20, 2020). Perm: IPC "Prokrost", 224-227 (2020)

16. I.P. Kondrakhin, A.V. Arkhipov, V.I. Levchenko, et al. Methods of veterinary clinical laboratory diagnostics, 520 (M.: KolosS, 2004)

17. G.H. Counotte, R.A. Prins, Vet Res Commun. Dec. 5 (2), 101-15 (1981)

18. A. Sederevicius, J. Kantautaité, Acta Vet Scand Suppl. 89, 19-24 (1993)

19. W. Zawadzki, Z. Hejłasz, J. Nicpoń, Pol Arch Weter. 31(3-4), 85-91 (1991) 